\title{
Polyhydramnios: Causes, Diagnosis and Therapy
}

\section{Das Polyhydramnion: Ursachen, Diagnostik und Therapie}

Authors

Affiliations
A. Hamza ${ }^{1}$, D. Herr ${ }^{1}$, E. F. Solomayer ${ }^{2}$, G. Meyberg-Solomayer ${ }^{1}$

${ }^{1}$ Gynäkologie und Geburtshilfe, Universitätsklinikum des Saarlandes, Homburg/Saar

${ }^{2}$ Klinik für Frauenheilkunde, Geburtshilfe und Reproduktionsmedizin, Universitätsklinikum des Saarlandes, Homburg/Saar

\section{Key words}

- polyhydramnios

- amniotic fluid

- high risk pregnancy

Schlüsselwörter

- Polyhydramnion

- Fruchtwasser

- Risikoschwangerschaft

Deutschsprachige Zusatzinformationen online abrufbar unter: www.thieme-connect.de/ ejournals/toc/gebfra

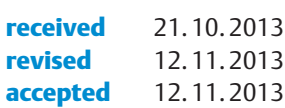

Bibliography

DOI http://dx.doi.org/

10.1055/s-0033-1360163

Geburtsh Frauenheilk 2013; 73:

1241-1246 @ Georg Thieme

Verlag KG Stuttgart · New York · ISSN 0016-5751

\section{Correspondence}

Mr. Amr Hamza, Postgraduate Universitätsklinikum des Saarlandes Gynäkologie und Geburtshilfe Kirrberger Straße 100 66424 Homburg/Saar Dramrh@gmail.com

\section{Abstract \\ $\nabla$}

Polyhydramnios is defined as a pathological increase of amniotic fluid volume in pregnancy and is associated with increased perinatal morbidity and mortality. Common causes of polyhydramnios include gestational diabetes, fetal anomalies with disturbed fetal swallowing of amniotic fluid, fetal infections and other, rarer causes. The diagnosis is obtained by ultrasound. The prognosis of polyhydramnios depends on its cause and severity. Typical symptoms of polyhydramnios include maternal dyspnea, preterm labor, premature rupture of membranes (PPROM), abnormal fetal presentation, cord prolapse and postpartum hemorrhage. Due to its common etiology with gestational diabetes, polyhydramnios is often associated with fetal macrosomia. To prevent the above complications, there are two methods of prenatal treatment: amnioreduction and pharmacological treatment with non-steroidal anti-inflammatory drugs (NSAIDs). However, prenatal administration of NSAIDs to reduce amniotic fluid volumes has not been approved in Germany. In addition to conventional management, experimental therapies which would alter fetal diuresis are being considered.

\section{Introduction}

Polyhydramnios is the term used to describe an excess accumulation of amniotic fluid. This clinical condition is associated with a high risk of poor pregnancy outcomes [1-3]. The reported prevalence of polyhydramnios ranges from 0.2 to $1.6 \%$ of all pregnancies [4-7].

\section{Zusammenfassung \\ $\nabla$}

Als Polyhydramnion bezeichnet man eine pathologische Vermehrung von Fruchtwasser bei der Schwangeren, die mit einer erhöhten perinatalen Morbidität und Mortalität vergesellschaftet ist. Häufige Ursachen eines Polyhydramnions sind der Gestationsdiabetes, fetale Fehlbildungen, die z.B. zu einem gestörten Schluckvorgang von Fruchtwasser führen, fetale Infektionen und andere seltene Ursachen. Die Diagnostik des Polyhydramnions erfolgt dabei v.a. sonografisch. Die Prognose des Polyhydramnions hängt von der Ursache sowie der klinischen Ausprägung ab: Typische Folgen des Polyhydramnions beinhalten maternale Atembeschwerden, die Frühgeburtlichkeit, den vorzeitigen Blasensprung, regelwidrige Kindslagen, den Nabelschnurvorfall, sowie die postpartale Blutung. Aufgrund einer gemeinsamen Ätiologie mit einem Gestationsdiabetes ist das Polyhydramnion darüber hinaus mit einer fetalen Makrosomie assoziiert. Zur Vermeidung der o.g. Komplikationen bestehen pränatal grundsätzlich 2 Therapieformen: die invasive Entlastungspunktion und die medikamentöse Amnionreduktion mit z.B. Non-Steroidal Anti-inflammatory drugs (NSAID), die jedoch in Deutschland bei dieser Indikation nicht zugelassen sind. Darüber hinaus gibt es in jüngster Zeit experimentelle Therapieansätze, die auf die Beeinflussung der fetalen Diurese zielen.

Under physiological conditions there is a dynamic equilibrium between the production and resorption of amniotic fluid. Fluid levels are influenced by fetal urination and fetal lung liquid production. Amniotic fluid is reabsorbed by fetal swallowing and intramembranous and intravascular absorption. The relative attribution of each of these mechanisms varies over the course of the pregnancy. A disturbed equilibrium can be the result 
of compromised swallowing function or increased urination and can lead to polyhydramnios [8-11].

A fetus close to term will produce between $500-1200 \mathrm{ml}$ urine and swallow between $210-760 \mathrm{ml}$ of amniotic fluid per day. Even small changes in this equilibrium can result in significant changes in amniotic fluid volumes [9-11].

\section{Etiology \\ $\nabla$}

An underlying disease is only found in $17 \%$ of cases in mild polyhydramnios. In contrast, an underlying disease is detected in $91 \%$ of cases in moderate to severe polyhydramnios [5]. The literature lists the following potential etiologies $[5,7,12-19]$ :

- fetal malformations and genetic anomalies (8-45\%)

- maternal diabetes mellitus (5-26\%)

- multiple pregnancies (8-10\%)

- fetal anemia (1-11\%)

- other causes, e.g. viral infections, Bartter syndrome, neuromuscular disorders, maternal hypercalcemia. Viral infections which can lead to polyhydramnios include parvovirus B19, rubella, and cytomegalovirus. Other infections, e.g. toxoplasmosis and syphilis, can also cause polyhydramnios [80-82].

Advances in detailed ultrasound scanning and the prevention of Rhesus isoimmunization in the last decades have changed the relative frequency of these etiologies and significantly reduced the number of idiopathic cases [12-19].

Well-known malformations which impair the swallowing reflex include esophageal atresia, duodenal atresia $[16,17]$ and neuromuscular disorders such as myotonic dystrophy. Increased urine production, as occurs with increased cardiac output associated with fetal anemia, can also result in increased production of amniotic fluid $[20,21]$. These changes can also occur in the context of chromosomal disorders such as trisomy 21 and different syndromes. Duodenal atresia is the most important etiology in cases with trisomy 21 [79].

Poorly managed gestational diabetes is associated with fetal macrosomia and polyhydramnios but the pathogenesis has not been elucidated yet [22]. One possible explanation is fetal hyperglycemia resulting in increased osmotic diuresis which subsequently leads to polyuria. This theory is supported by evidence of a strong association with high glycosylated hemoglobin values $\left(\mathrm{HBA}_{1 \mathrm{c}}\right)$ in cases with polyhydramnios $[22,23]$. According to the AWMF S3-guideline, polyhydramnios can be an indication of diabetogenic fetopathy. However, due to the wide range in amniotic fluid volumes, polyhydramnios does not play an important role in monitoring gestational diabetes [68]. The prevalence of polyhydramnios in maternal cases with diabetes mellitus is $18.8 \%$ [23]. As the cause could also be fetal metabolic syndrome, children born after pregnancy complicated by polyhydramnios should be followed up by a pediatrician $[24,25]$.

\section{Ultrasound Assessment of Amniotic Fluid Volume} $\nabla$

Ultrasound and subjective or semi-quantitative assessment is used to evaluate amniotic fluid volumes. With the subjective method, the examiner estimates the volume of amniotic fluid based on personal impressions of the amniotic fluid depot. The sonographer's experience plays an important role here [26]. When evaluating cases of oligo- or polyhydramnios, the use of biometric measurements and references is more accurate when examiners are less experienced, while evaluation based solely on subjective assessment is associated with good results if done by an experienced examiner [27].

Various semi-quantitative methods to measure amniotic fluid volumes have been described. But these methods also have their limitations which must be taken into account [28].

\section{Single deepest pocket measurement}

For this type of measurement the uterus is divided into four quadrants. The amniotic fluid volume is measured vertically in the deepest amniotic fluid pocket. Values below $2 \mathrm{~cm}$ indicate oligohydramnios, values over $8 \mathrm{~cm}$ indicate polyhydramnios [30]. The advantage of this method is its simplicity, making it the most commonly used method in practice. It is also the method of choice in multiple gestation. In cases with multiple gestation, a range of $3-8 \mathrm{~cm}$ is defined as normal. With this method, polyhydramnios is classified as mild, moderate or severe. Mild polyhydramnios is characterized by a value of $8-11 \mathrm{~cm}$, moderate polyhydramnios by a value between $12-15 \mathrm{~cm}$ and severe

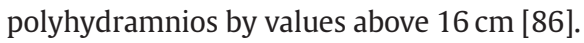

\section{The 4-quadrant method (AFI - Amniotic Fluid Index)}

With this method, the deepest amniotic pocket in each of the four quadrants is measured vertically and the values added together. The uterus is divided vertically into two halves by an imaginary line along the linea nigra. An imaginary horizontal line through the umbilicus divides the uterus into an upper and a lower half. During measurement the transducer is held at right angles to the sagittal plane of the patient's abdomen. The transducer should not be tilted along the maternal abdomen, i.e. it must be kept at a right angle. The measured amniotic fluid pockets must be free of fetal extremities and the umbilical cord and must be at least $0.5 \mathrm{~cm}$ wide. The Amniotic Fluid Index (AFI) is the sum of measurements of all four quadrants. According to one study group, AFI values between 8.1 and $18 \mathrm{~cm}$ are normal, values between 5.1 und $8.0 \mathrm{~cm}$ indicate oligohydramnios, an AFI value of less than $5.0 \mathrm{~cm}$ indicates severe oligohydramnios and a value above $18 \mathrm{~cm}$ is classified as polyhydramnios [31].

Based on AFI values obtained during prenatal screening, some clinicians categorize polyhydramnios into three groups according to severity: mild polyhydramnios (AFI of $25-30 \mathrm{~cm}$ ), moderate polyhydramnios $(30.1-35 \mathrm{~cm})$ and severe polyhydramnios $(\geq 35.1 \mathrm{~cm})$ [87].

Moore und Cayle [32] investigated the distribution of AFI measurements in a population with normal pregnancies. In contrast to the definition of oligohydramnios proposed by Phelan et al. (AFI less than $5 \mathrm{~cm}$ [31]) they found that an AFI of $5 \mathrm{~cm}$ was only found in $1 \%$ of normal pregnancies. Intraobserver variation ranged between 0.5 and $1 \mathrm{~cm}$, and interobserver variation was between 1 and $2 \mathrm{~cm}$. Taking the calculated average of three measurements is recommended to achieve the greatest accuracy, particularly when the AFI is less than $10 \mathrm{~cm}$ [32]. The use of color flow Doppler has the advantage that umbilical cord loops are detected more easily. But, according to a retrospective study by Zlatnik et al. [34], AFI measured with color flow Doppler overestimated oligohydramnios and underestimated polyhydramnios if standard AFI tables (obtained without color flow Doppler) were used [33,34].

It should be noted that the pressure exerted by the transducer can change AFI and single deepest pocket measurements. If the pressure is minimal, AFI increases by $13 \%$, while if strong pressure is exerted, AFI is underestimated by $21 \%$ [35-38]. 


\section{Amniotic fluid quantification in}

the German Maternity Guidelines

In the German Maternity Guidelines, assessment of amniotic fluid is a standard examination in prenatal care. Oligohydramnios and polyhydramnios are considered indicative of a developmental disorder. If there is a suspicion of a developmental disorder, regular follow-up examinations and further diagnostic tests are recommended [69]. The diagnosis of polyhydramnios appears to be independent of gestational week. An enlarged amnion at the first ultrasound scan in the 7th week of gestation is associated with early embryonic death $[70,71]$. However different constellations can affect prognosis. Polyhydramnios combined with a small for gestational age (SGA) fetus has a particularly poor prognosis as this combination is associated with a high incidence of malformations. Typically, trisomy 18 is a suspected diagnosis $[72,73]$. In a monochoriotic diamniotic twin pregnancy with polyhydramnios in the amniotic sac of one fetus and oligohydramnios in the amniotic sac of the other, the cause is often feto-fetal transfusion syndrome [74-77].

\section{Comparison of the two methods (AFI and SDP)}

The goal of amniotic fluid volume quantification is to detect amniotic fluid pathologies associated with poor outcomes rather than to determine the actual amniotic fluid volume [29]. A systematic review of randomized studies found no evidence that one method was superior to another $[39,40,41,89]$. Significantly more cases of oligohydramnios were diagnosed using the AFI method. But there were no significant differences between methods with regard to prognosis of perinatal outcome in post-term pregnancies. However, single deepest pocket (SDP) measurement is the method of choice in multiple pregnancies as it is simpler to perform and equally effective [90-98].

\section{Further Diagnostic Tests when Polyhydramnios is Present \\ $\nabla$}

\section{Ultrasound investigation}

The fetus should be examined carefully during fetal organ screening. The anomalies most commonly missed at screening are tracheoesophageal fistula, cardiac septal defects and cleft palate [7]. If a fetal malformation or several soft markers are present, fetal karyotyping is recommended after obtaining informed parental consent in accordance with the German Genetic Diagnosis Act [42-45]. In a large study, the prevalence of aneuploidy in fetal anomalies was found to be $10 \%(95 \% \mathrm{CI}$ : $5-19 \%$ ) [7]. The risk of fetal malformation in cases with severe polyhydramnios has been reported to increase to $11 \%$, but this figure is still discussed controversially. The risk of fetal anomalies is $1 \%$ with mild polyhydramnios and $2 \%$ with moderate polyhydramnios $2 \%$ [99]. In Germany, a detailed ultrasound scan done in an experienced prenatal center (DEGUM II/III [German Society for Ultrasound Medicine]) is recommended if there is a high degree of suspicion of fetal malformation.

Some causes, e.g. swallowing disorders and tracheoesophogeal fistula or atresia can be completely overlooked by ultrasound. In this case, fetal MRI can offer a better alternative in the diagnosis of tracheoesophogeal fistula or atresia in utero [82-85].

\section{Laboratory tests}

Laboratory tests to identify causes of polyhydramnios should include:

- $75 \mathrm{~g}$ oral glucose tolerance test (OGTT) to exclude gestational diabetes

- maternal diagnostic testing for infection (ToRCH serology)

- if there is a suspicion of fetal anemia or fetal hydrops, tests to exclude immunological causes (maternal blood group, Rhesus factor, screening for antibodies) and hematological disorders (possibly Kleihauer-Betke test to exclude fetomaternal hemorrhage) are indicated. The literature also lists certain drugs, e.g. lithium, which are associated with a higher incidence of polyhydramnios. Lithium is a psychotropic drug prescribed prenatally, e.g. to treat bipolar disorders [100].

Severe fetal anemia is frequently associated with pleural and pericardial effusion, ascites and/or skin edema. Measurement of middle cerebral artery peak systolic velocity is a useful method to diagnose fetal anemia; fetuses with a peak systolic velocity $>1.5$ MoM have a strong risk of anemia.

Intrauterine infection may be suspected based on maternal symptoms or fetal abnormalities such as hydrocephalus due to toxoplasmosis.

\section{Prognosis}

$\nabla$

The risk of the following obstetric complications is increased when polyhydramnios is present due to over-expansion of the uterus $[1,46,47]$ :

- maternal dyspnea

- preterm labor

- premature rupture of membranes

- abnormal fetal presentation

- umbilical cord prolapse

- postpartum hemorrhage

- fetal macrosomia due to maternal diabetes mellitus

- hypertensive disorders of pregnancy

- urinary tract infections

These risks vary depending on the severity and etiology of the polyhydramnios [1-3]. Perinatal mortality increased 13-fold when the single deepest pocket was less than $2 \mathrm{~cm}$; when the SDP was less than $1 \mathrm{~cm}$, perinatal mortality increased 47 -fold [26].

A prospective longitudinal study of normal singleton pregnancies lists the following potential complications [34]:

- higher rates of cesarean sections for fetal indications

- higher rates of admission to neonatal intensive care units

- higher birth weight

- lower 5-minute Apgar scores

In a large study of 85000 pregnancies, of which 3900 pregnancies had an increased AFI, it was found that polyhydramnios was an independent risk factor for perinatal mortality [48]. Small for gestational age (SGA) fetuses with polyhydramnios had the poorest prognosis [78].

\section{Treatment Options to Reduce Amniotic Fluid Volume $\nabla$}

Treatment consists of reducing the volume of amniotic fluid to improve maternal well-being and prolong the pregnancy. The following methods are used to reduce amniotic fluid volumes: 
- amnioreduction (therapeutic amniocentesis) [53-55]

- pharmacological treatment [49-52]

\section{Amnioreduction}

To date, this method has not been evaluated in randomized or controlled studies, but it offers a clear clinical benefit if done after careful diagnostic evaluation. However, there is no consensus regarding the volume of aspirated amniotic fluid, the speed of aspiration and the use of tocolytics or antibiotics. The intervention is usually concluded when ultrasound examination shows an AFI of 15 to $20 \mathrm{~cm}$ or if intra-amniotic pressure drops to $<20 \mathrm{mmHg}$ $[53,66]$. In some cases, the intervention had to be terminated due to maternal discomfort or premature placental abruption. Tocolytics are routinely used as prophylaxis to prevent onset of preterm labor.

Complications occur in 1-3\% of cases and can include premature labor, placental abruption, premature rupture of membranes, hyperproteinemia and amniotic infection syndrome [52,54]. After the procedure, regular monitoring of amniotic fluid volumes is recommended, with monitoring done every 1 to 3 weeks.

\section{Prostaglandin synthetase inhibitor}

Prostaglandin synthetase inhibitors stimulate fetal secretion of arginine vasopressin, resulting in vasopressin-induced antidiuresis $[49,57,58,62]$. Reduced renal blood flow reduces fetal urine production. These substances can also inhibit fetal lung liquid production or increase reabsorption rates [56].

However, prostaglandin synthetase inhibitors have not been approved for this indication in pregnancy in Germany.

While these substances are used as an analgesic or in anti-inflammatory therapy in the 1st and 2nd trimesters of pregnancy, patients are advised against using these substances after the 28th week of gestation [88]. It should be noted that the use of these drugs is not generally approved in pregnancy.

\section{Sulindac}

Sulindac is a non-steroidal anti-inflammatory drug; use of sulindac can also lead to a reduction of amniotic fluid volume. There are some reports that sulindac decreases pulsatility in fetal ductus arteriosus less than indomethacin [58-61]. However, the efficacy of sulindac has not been confirmed by further studies yet.

\section{Potential Future Experimental Therapies \\ $\nabla$}

As fetal urine production constitutes the main source of amniotic fluid and changes in urine production can significantly change the dynamics of amniotic fluid volumes, the effect of intra-amniotic administration of arginine vasopressin was investigated. Arginine vasopressin is absorbed into fetal plasma from the intraamniotic fluid. The effects of a V2 receptor agonist, deamino(DArg8)-vasopressin, on fetal plasma arginine vasopressin immunoreactivity, fetal urine production and swallowing was investigated in 6 individual ovine pregnancies. It was demonstrated that intra-amniotic administration of deamino(D-Arg8)-vasopressin resulted in persistent fetal antidiuresis with no cardiovascular effects and no changes in fetal swallowing. Even though the data do not permit a general conclusion to be drawn, these results indicate this could be a potential therapy for polyhydramnios [63]. Another potential therapy is based on mRNA expression in chorion and amnion cells of aquaporin (AQP) 1, 8 und 9 in amniotic fluid, which is increased in polyhydramnios. Aquaporins are water channel proteins which regulate the flow of water across cellular membranes. AQP1 expression could represent a compensatory response to polyhydramnios. The effect of reducing this protein on polyhydramnios requires further study $[64,65]$. The efficacy and safety of these experimental therapeutic approaches should be investigated in prospective randomized studies.

\section{Monitoring of Pregnancies with Polyhydramnios $\nabla$}

In view of the increased perinatal mortality and morbidity associated with pregnancies with polyhydramnios, careful monitoring is recommended [46].

\section{Expectant management vs. intervention}

There are no prospective randomized studies comparing expectant management to active intervention in idiopathic polyhydramnios [1]. Intervention is generally recommended in cases with severe maternal discomfort or obstetric complications, e.g. premature labor.

\section{Delivery}

Fetal head presentation should be checked several times during labor, as fetal position change to breech presentation or transverse lie can occur intrapartum.

Spontaneous rupture of membranes can lead to acute uterine decompression with the risk of cord prolapse or placental abruption. Artificial rupture of membranes should therefore only be done under controlled conditions.

Although polyhydramnios does not constitute a contraindication for the application of oxytocin or prostaglandins, these substances should be administered with care. There is an increased risk of atonic bleeding and amniotic-fluid embolism postpartum $[57,67]$.

\section{Conclusion}

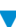

Polyhydramnios diagnosed on ultrasound requires further maternal and fetal diagnostic tests. Maternal gestational diabetes should be excluded and maternal ToRCH screening is recommended. Detailed morphological testing should be planned for the fetus. Delivery in a perinatal center is recommended.

\section{Conflict of Interest}

None.

\section{References}

1 Golan A, Wolman I, Sagi J et al. Persistence of polyhydramnios during pregnancy - its significance and correlation with maternal and fetal complications. Gynecol Obstet Invest 1994; 37: 18

2 Many A, Hill LM, Lazebnik $N$ et al. The association between polyhydramnios and preterm delivery. Obstet Gynecol 1995; 86: 389

3 Smith CV, Plambeck RD, Rayburn WF et al. Relation of mild idiopathic polyhydramnios to perinatal outcome. Obstet Gynecol 1992; 79: 387

4 Alexander ES, Spitz HB, Clark RA. Sonography of polyhydramnios. AJR Am J Roentgenol 1982; 138: 343

5 Hill LM, Breckle R, Thomas ML et al. Polyhydramnios: ultrasonically detected prevalence and neonatal outcome. Obstet Gynecol 1987; 69: 21

6 Hobbins JC, Grannum PA, Berkowitz RL et al. Ultrasound in the diagnosis of congenital anomalies. Am J Obstet Gynecol 1979; 134: 331 
7 Dashe JS, McIntire DD, Ramus RM et al. Hydramnios: anomaly prevalence and sonographic detection. Obstet Gynecol 2002; 100: 134

8 Brace RA. Physiology of amniotic fluid volume regulation. Clin Obstet Gynecol 1997; 40: 280

9 Harding R, Bocking AD, Sigger JN et al. Composition and volume of fluid swallowed by fetal sheep. QJ Exp Physiol 1984; 69: 487

10 Pritchard JA. Deglutition by normal and anencephalic fetuses. Obstet Gynecol 1965; 25: 289

11 Pritchard JA. Fetal swallowing and amniotic fluid volume. Obstet Gynecol 1966; 28: 606

12 Phelan JP, Martin GI. Polyhydramnios: fetal and neonatal implications. Clin Perinatol 1989; 16: 987

13 Ledger WF. Maternal Infection with adverse fetal and newborn Outcomes. In: Infection in the Female. Philadelphia: Lea \& Febiger; 1986: 197

14 Queenan JT, Gadow EC. Polyhydramnios: chronic versus acute. Am J Obstet Gynecol 1970; 108: 349

15 Murray SR. Hydramnios: a study of 846 cases. Am J Obstet Gynecol 1964; 88: 65

16 Ben-Chetrit A, Hochner-Celnikier D, Ron $M$ et al. Hydramnios in the third trimester of pregnancy: a change in the distribution of accompanying fetal anomalies as a result of early ultrasonographic prenatal diagnosis. Am J Obstet Gynecol 1990; 162: 1344

17 Stoll CG, Alembik Y, Dott B. Study of 156 cases of polyhydramnios and congenital malformations in a series of 118,265 consecutive births. Am J Obstet Gynecol 1991; 165: 586

18 Shani H, Sivan E, Cassif E et al. Maternal hypercalcemia as a possible cause of unexplained fetal polyhydramnion: a case series. Am J Obstet Gynecol 2008; 199: 410.e1

19 Dorleijn DM, Cohen-Overbeek TE, Groenendaal $F$ et al. Idiopathic polyhydramnios and postnatal findings. J Matern Fetal Neonatal Med 2009; 22: 315

20 Sieck UV, Ohlsson A. Fetal polyuria and hydramnios associated with Bartter's syndrome. Obstet Gynecol 1984; 63: 22S

21 Lee SM, Jun JK, Lee EJ et al. Measurement of fetal urine production to differentiate causes of increased amniotic fluid volume. Ultrasound Obstet Gynecol 2010; 36: 191

22 Vink JY, Poggi SH, Ghidini A et al. Amniotic fluid index and birth weight: is there a relationship in diabetics with poor glycemic control? Am J Obstet Gynecol 2006; 195: 848

23 Idris N, Wong SF, Thomae $M$ et al. Influence of polyhydramnios on perinatal outcome in pregestational diabetic pregnancies. Ultrasound $\mathrm{Ob}-$ stet Gynecol 2010; 36: 338

24 Touboul C, Boileau P, Picone $O$ et al. Outcome of children born out of pregnancies complicated by unexplained polyhydramnios. BJOG 2007; 114: 489

25 Touboul C, Picone O, Levaillant JM et al. Clinical application of fetal urine production rate in unexplained polyhydramnios. Ultrasound Obstet Gynecol 2009; 34: 521

26 Halperin ME, Fong $K W$, Zalev AH et al. Reliability of amniotic fluid volume estimation from ultrasonograms: intraobserver and interobserver variation before and after the establishment of criteria. Am J Obstet Gynecol 1985; 153: 264-267

27 Magann EF, Perry KG, Chauhan SP et al. The accuracy of ultrasound evaluation of amniotic fluid volume in singleton pregnancies: the effect of operator experience and ultrasound interpretative technique. J Clin Ultrasound 1997; 25: 249-253

28 Magann EF, Isler CM, Chauhan SP et al. Amniotic fluid volume estimation and the biophysical profile: a confusion criteria. Obstet Gynecol 2000; 96: 640-642

29 Chamberlain PF, Manning FA, Morrison I et al. Ultrasound evaluation of amniotic volume. I. The relationship of marginal and decreased amniotic fluid volume to perinatal outcome. Am J Obstet Gynecol 1984; 150: $245-249$

30 Manning FA, Harmon CR, Morrison I. Fetal assessment based on fetal biophysical profile scoring. IV. An analysis of perinatal morbidity and mortality. Am J Obstet Gynecol 1990; 162: 703-709

31 Phelan JP, Ahn MO, Smith CV et al. Amniotic fluid index measurements during pregnancy. J Reprod Med 1987; 32: 601-604

32 Moore TR, Cayle JE. The amniotic fluid index in normal human pregnancy. Am J Obstet Gynecol 1990; 162: 1168-1173

33 Magann EF, Whithworth NS, Klausen JH et al. Accuracy of ultrasonography in evaluating amniotic fluid index at less than 24 weeks' gestation. J Ultrasound Med 1995; 14: 895-897
34 Zlatnik MG, Olson G, Bukowski R et al. Amniotic fluid index measured with the aid of color flow Doppler. J Matern Fetal Med 2003; 13: 242245

35 Flack NJ, Doré C, Southwell D et al. The influence of operator transducer pressure on ultrasonographic measurements of amniotic fluid volume. Am J Obstet Gynecol 1994; 171: 218-222

36 Magann EF, Nolan TE, Hess LW et al. Measurements of amniotic fluid volume: accuracy of ultrasonography techniques. Am J Obstet Gynecol 1992: 167: 1533-1537

37 Gramellini D, Delle Chiaie L, Piantelli G et al. Sonographic assessment of amniotic fluid volume between 11 and 24 weeks of gestation: construction of reference intervals related to gestational age. Ultrasound Obstet Gynecol 2001; 17: 410-415

38 Magann EF, Chauhan SP, Barilleaux PS et al. Amniotic fluid index and single deepest pocket: weak indicators of abnormal amniotic volumes. Obstet Gynecol 2000; 96: 737-740

39 Magann EF, Chauhan SP, Barrilleaux PS et al. Amniotic fluid index and single deepest pocket: weak indicators of abnormal amniotic volumes. Obstet Gynecol 2000; 96: 737

40 Barnhard Y, Bar-Hava I, Divon MY. Is polyhydramnios in an ultrasonographically normal fetus an indication for genetic evaluation? Am J Obstet Gynecol 1995; 173: 1523

41 Chauhan SP, Magann EF, Morrison JC et al. Ultrasonographic assessment of amniotic fluid does not reflect actual amniotic fluid volume. Am J Obstet Gynecol 1997; 177: 291

42 Landy HJ, Isada NB, Larsen jr. JW. Genetic implications of idiopathic hydramnios. Am J Obstet Gynecol 1987; 157: 114

43 Brady K, Polzin WJ, Kopelman JN et al. Risk of chromosomal abnormalities in patients with idiopathic polyhydramnios. Obstet Gynecol 1992; 79: 234

44 Carlson DE, Platt $L D$, Medearis $A L$ et al. Quantifiable polyhydramnios: diagnosis and management. Obstet Gynecol 1990; 75: 989

45 Zahn CM, Hankins GD, Yeomans ER. Karyotypic abnormalities and hydramnios. Role of amniocentesis. J Reprod Med 1993; 38: 599

46 Magann EF, Chauhan SP, Doherty DA et al. A review of idiopathic hydramnios and pregnancy outcomes. Obstet Gynecol Surv 2007; 62 : 795

47 Magann EF, Doherty DA, Lutgendorf MA et al. Peripartum outcomes of high-risk pregnancies complicated by oligo- and polyhydramnios: a prospective longitudinal study. J Obstet Gynaecol Res 2010; 36: 268

48 Erez O, Shoham-Vardi I, Sheiner E et al. Hydramnios and small for gestational age are independent risk factors for neonatal mortality and maternal morbidity. Arch Gynecol Obstet 2005; 271: 296

49 Cabrol D, Landesman R, Muller J et al. Treatment of polyhydramnios with prostaglandin synthetase inhibitor (indomethacin). Am J Obstet Gynecol 1987; 157: 422

50 Hickok DE, Hollenbach KA, Reilley SF et al. The association between decreased amniotic fluid volume and treatment with nonsteroidal antiinflammatory agents for preterm labor. Am J Obstet Gynecol 1989; 160: 1525

51 Kirshon B, Mari G, Moise jr. KJ. Indomethacin therapy in the treatment of symptomatic polyhydramnios. Obstet Gynecol 1990; 75: 202

52 Elliott JP, Sawyer AT, Radin TG et al. Large-volume therapeutic amniocentesis in the treatment of hydramnios. Obstet Gynecol 1994; 84: 1025

53 Fisk NM, Tannirandorn Y, Nicolini $U$ et al. Amniotic pressure in disorders of amniotic fluid volume. Obstet Gynecol 1990; 76: 210

54 Leung WC, Jouannic JM, Hyett J et al. Procedure-related complications of rapid amniodrainage in the treatment of polyhydramnios. Ultrasound Obstet Gynecol 2004; 23: 154

55 Jauniaux E, Holmes A, Hyett J et al. Rapid and radical amniodrainage in the treatment of severe twin-twin transfusion syndrome. Prenat Diagn 2001; 21: 471

56 Kramer WB, Van den Veyver IB, Kirshon B. Treatment of polyhydramnios with indomethacin. Clin Perinatol 1994; 21: 615

57 Harman CR. Amniotic fluid abnormalities. Semin Perinatol 2008; 32: 288

58 Moise jr. KJ. Polyhydramnios. Clin Obstet Gynecol 1997; 40: 266

59 Bartfield M, Carlan SJ. The safety and efficacy of prolonged outpatient sulindac to prevent the recurrence of preterm labor: a prospective double-blind study. Prim Care Update Ob Gyns 1998; 5: 178

60 Kramer WB, Saade GR, Belfort M et al. A randomized double-blind study comparing the fetal effects of sulindac to terbutaline during the management of preterm labor. Am J Obstet Gynecol 1999; 180: 396 
61 Peek MJ, McCarthy A, Kyle P et al. Medical amnioreduction with sulindac to reduce cord complications in monoamniotic twins. Am J Obstet Gynecol 1997; 176: 334

62 Gilbert WM, Cheung CY, Brace RA. Rapid intramembranous absorption into the fetal circulation of arginine vasopressin injected intraamniotically. Am J Obstet Gynecol 1991; 164: 1013

63 Kullama LK, Nijland MJ, Ervin MG et al. Intraamniotic deamino(DArg8)-vasopressin: prolonged effects on ovine fetal urine flow and swallowing. Am J Obstet Gynecol 1996; 174: 78

64 Mann SE, Dvorak N, Gilbert $H$ et al. Steady-state levels of aquaporin $1 \mathrm{mRNA}$ expression are increased in idiopathic polyhydramnios. Am J Obstet Gynecol 2006; 194: 884

$65 \mathrm{Zhu}$ X, Jiang S, Hu Yet al. The expression of aquaporin 8 and aquaporin 9 in fetal membranes and placenta in term pregnancies complicated by idiopathic polyhydramnios. Early Hum Dev 2010; 86: 657

66 Rode L, Bundgaard A, Skibsted L et al. Acute recurrent polyhydramnios: a combination of amniocenteses and NSAID may be curative rather than palliative. Fetal Diagn Ther 2007; 22: 186

67 Kramer MS, Rouleau J, Baskett TF et al. Amniotic-fluid embolism and medical induction of labour: a retrospective, population-based cohort study. Lancet 2006; 368: 1444

68 Kleinwechter H, Bührer C, Hunger-Battefeld W et al. AWMF-S3-Leitlinie: Diabetes und Schwangerschaft. Online: http://www.awmf.org/ leitlinien/detail/1l/057-023.html; last access: 06.11.2013

69 Richtlinien des Gemeinsamen Bundesausschusses über die ärztliche Betreuung während der Schwangerschaft und nach der Entbindung („Mutterschafts-Richtlinien“) in der Fassung 10. Dezember 1985. Veröffentlicht im Bundesanzeiger Nr. 60 a vom 27. März 1986, zuletzt geändert am 18. Juli 2013, in Kraft getreten am 20. September 2013

70 Horrow MM. Enlarged amniotic cavity: a new sonographic sign of early embryonic death. AJR Am J Roentgenol 1992; 158: 359-362

71 Yegul NT, Filly RA. The expanded amnion sign: evidence of early embryonic death. J Ultrasound Med 2009; 28: 1331-1335

72 Erez O, Shoham-Vardo I, Sheiner E et al. Hydramnios and small for gestational age are independent risk factors for neonatal mortality and maternal morbidity. Arch Gynecol Obstet 2004; 271: 296

73 Sickler GK, Nyberg DA, Sohaey R et al. Polyhydramnios and fetal intrauterine growth restriction: ominous combination. J Ultrasound Med 1997; 16: 609-614

74 Morin L, Lim K. Ultrasound in twin pregnancies. J Obstet Gynaecol Can 2011; 33: 643-656

75 National Collaborating Centre for Women's and Children's Health (UK). Multiple pregnancy: the management of twin and triplet pregnancies in the antenatal period. London: RCOG Press; 2011. National Institute for Health and Clinical Excellence: Guidance

76 Gezer A, Rashidova M, Güralp 0 et al. Perinatal mortality and morbidity in twin pregnancies: the relation between chorionicity and gestational age at birth. Arch Gynecol Obstet 2012; 285: 353-360

77 Hack KE, Derks JB, Elias SG et al. Perinatal mortality and mode of delivery in monochorionic diamniotic twin pregnancies $\geq 32$ weeks of gestation: a multicentre retrospective cohort study. BJOG 2011; 118 : 1090-1097

78 Nyberg DA, Kramer D, Resta RG et al. Prenatal sonographic findings of trisomy 18: review of 47 cases. J Ultrasound Med 1993; 12: 103-113

79 Papp C, Szigeti Z, Tóth-Pál E et al. Ultrasonographic findings of fetal aneuploidies in the second trimester - our experiences. Fetal Diagn Ther 2008; 23: 105
80 Fayyaz H, Rafi J. TORCH screening in polyhydramnios: an observational study. J Matern Fetal Neonatal Med 2012; 25: 1069

81 Abdel-Fattah SA, Bhat A, Illanes $S$ et al. TORCH test for fetal medicine indications: only CMV is necessary in the United Kingdom. Prenat Diagn 2005; 25: 1028-1031

82 Mladina N, Mehikić G, Pasić A. [TORCH infections in mothers as a cause of neonatal morbidity]. Med Arh 2000; 54: 273-276

83 Salomon LJ, Sonigo P, Ou P et al. Real-time fetal magnetic resonance imaging for the dynamic visualization of the pouch in esophageal atresia. Ultrasound Obstet Gynecol 2009; 34: 471-474

84 Langer JC, Hussain H, Khan A et al. Prenatal diagnosis of esophageal atresia using sonography and magnetic resonance imaging. J Pediatr Surg 2001; 36: 804-807

85 Chaumoître K, Amous Z, Bretelle $F$ et al. Prenatal MRI diagnosis of esophageal atresia. J Radiol 2004; 85 (12 Pt 1): 2029-2031

86 Chen $M$, Chen CP. Invasive fetal therapy, global status and local development. Taiwanese J Obstet Gynecol 2004; 439: 185-192

87 Magann EF, Chauhan SP, Doherty DA et al. A review of idiopathic hydramnios and pregnancy outcomes. Obstet Gynecol Surv 2007; 62: 795-802

88 Embryotoxikologisches Institut. Diclofenac in der Schwangerschaft. Online: https://www.embryotox.de/diclofenac.html; last access: 20.11.2013

89 Nabhan AF, Abdelmoula YA. Amniotic fluid index versus single deepest vertical pocket as a screening test for preventing adverse pregnancy outcome. Cochrane Database Syst Rev 2008; 3: CD006593

90 Chauhan SP, Doherty DD, Magann EF et al. Amniotic fluid index vs. single deepest pocket technique during modified biophysical profile: a randomized clinical trial. Am J Obstet Gynecol 2004; 191: 661

91 Magann EF, Doherty DA, Ennen CS et al. The ultrasound estimation of amniotic fluid volume in diamniotic twin pregnancies and prediction of peripartum outcomes. Am J Obstet Gynecol 2007; 196: 570.e1

92 Gerson A, Free jr. SM, Russino J et al. Amniotic fluid index in twin gestation. Ultrasound Obstet Gynecol 1997; 10: 98

93 Hill LM, Krohn M, Lazebnik $N$ et al. The amniotic fluid index in normal twin pregnancies. Am J Obstet Gynecol 2000; 182: 950

94 Magann EF, Chauhan SP, Martin jr. JN et al. Ultrasonic assessment of the amniotic fluid volume in diamniotic twins. J Soc Gynecol Investig 1995; 2: 609

95 Magann EF, Chauhan SP, Whitworth NS et al. Determination of amniotic fluid volume in twin pregnancies: ultrasonographic evaluation versus operator estimation. Am J Obstet Gynecol 2000; 182: 1606

96 Watson WJ, Harlass FE, Menard MK et al. Sonographic assessment of amniotic fluid in normal twin pregnancy. Am J Perinatol 1995; 12 : 122

97 Chau AC, Kjos SL, Kovacs BW. Ultrasonographic measurement of amniotic fluid volume in normal diamniotic twin pregnancies. Am J Obstet Gynecol 1996; 174: 1003

98 Porter TF, Dildy GA, Blanchard JR et al. Normal values for amniotic fluid index during uncomplicated twin pregnancy. Obstet Gynecol 1996; 87: 699

99 Dashe JS, McIntire DD, Ramus RM et al. Hydramnios: anomaly prevalence and sonographic detection. Obstet Gynecol 2002; 100: 134-139

100 Oyebode F, Rastogi A, Berrisford G et al. Psychotropics in pregnancy: safety and other considerations. Pharmacol Ther 2012; 135: 71-77 